\title{
Autobiography and conservative-nationalist political opposition in Early Republican Turkey
}

\section{Yasemin Ipek}

To cite this article: Yasemin Ipek (2018) Autobiography and conservative-nationalist political opposition in Early Republican Turkey, Turkish Studies, 19:1, 139-165, DOI: 10.1080/14683849.2017.1397516

To link to this article: https://doi.org/10.1080/14683849.2017.1397516

曲 Published online: 14 Nov 2017.

Submit your article to this journal

Џll Article views: 212

View Crossmark data $₫$ 


\title{
Autobiography and conservative-nationalist political opposition in Early Republican Turkey
}

\author{
Yasemin Ipek \\ Department of Political Science and Public Administration, Bilkent University, Ankara, Turkey
}

\begin{abstract}
This article examines how autobiography-writing evolved into a political space for Kazım Karabekir, Ali Fuat Cebesoy and Rauf Orbay, three major leaders of the Turkish War of Independence and the Progressive Republican Party. This article demonstrates that their autobiographies articulate a position of political opposition. This is a novel addition to academic literature that has so far presented these figures as early representatives of peripheral dissent against the Republic, or overstressed their Unionist legacy. The autobiographical politics of Karabekir, Cebesoy and Orbay extensively builds on moralizing discourses that contrast their own heroic accomplishments against the rise of a circle of military-bureaucratic elites - etraf - surrounding Mustafa Kemal Atatürk. Through textual analysis, this article maintains that the moralizing discourses they use pose a peculiar blend of nationalism and conservatism - an elitist conservative nationalism that homogenizes political differences and ideological splits. The analysis contributes to the study of Early Republican oppositional politics and conservative political imaginary in Turkey.
\end{abstract}

ARTICLE HISTORY Received 8 June 2016; Accepted 15 July 2017

KEYWORDS Conservative nationalism; Early Republican Turkey; autobiography; political opposition in Turkey; morality

\section{Introduction}

Kazım Karabekir, Ali Fuat Cebesoy and Rauf Orbay were not only among the prominent military and political figures of the late Ottoman Empire but were also the most intimate comrades of Mustafa Kemal, the founder of the Turkish Republic during the Turkish War of Independence, or the 'National Struggle' (milli mücadele). Their relationship with Mustafa Kemal worsened after the war, and Karabekir, Cebesoy and Orbay established Turkey's first opposition party in 1924, the Progressive Republican Party (Terakkiperver Cumhuriyet Firkasl, PRP), ${ }^{1}$ in competition with the Republican People's Party (Cumhuriyet Halk Firkası, RPP) ${ }^{2}$ founded by Mustafa Kemal. ${ }^{3}$ 
Following the Shaikh Said Rebellion in 1925, the PRP was closed down almost immediately, and the three were put on trial, yet were ultimately acquitted of all charges. ${ }^{4}$ After the closing down of the PRP, the political presence of Karabekir, Cebesoy and Orbay as oppositional figures against the emerging Republican political establishment was limited. During this period, they started organizing their personal notes and memoirs into autobiographical writings to be published to document their recollections of the Independence War and its aftermath. Karabekir, Cebesoy and Orbay use multiple genres of autobiographic writing (autobiography, personal memoir, daily notes and personal records about military activities) in order to recount post-war political developments from their own perspectives. ${ }^{5}$ Their uses of the literary genres of autobiographical writing ${ }^{6}$ opens up a peculiar political space to reconstruct history, appeal to future generations, and generate an opposition - which I call conservative nationalism.

There are two major tendencies in the literature on the PRP and its politics. The first tendency is to overstress the PRP's ideological difference from the RPP, presenting it as a conservative-traditionalist and peripheral opposition against a top-down modernist-secularist center. This article questions the dualistic binary these works rely on by underlining the elitist aspects of Karabekir, Cebesoy and Orbay's views in their autobiographical writings. The second tendency is, conversely, to overemphasize the Unionist political legacy they shared with Mustafa Kemal and the RPP. These works portray their opposition as an intra-elite struggle in a post-revolutionary political scene, and downplay their conservatism by reducing their ideological legacy to the liberal tenets of the party program, questioning whether the PRP leaders can be qualified as conservative at all. ${ }^{7}$ This analysis acknowledges the second approach's emphasis on the military-elite Unionist legacy the PRP leaders shared with Mustafa Kemal. On the other hand, overemphasizing this military-elite legacy, or the liberalism of their party program, underestimates the conservative and moralist contours of the oppositional politics articulated in their autobiographical writings. Hence, the basic contention in this article is that the overemphasis (i) on the party's popular reception as a vehicle for peripheral dissent during its short lifespan and (ii) on the liberal ideological tenets of the party program, obscures the complex layers of its leaders' oppositional politics, which extended beyond the party, and continued to evolve even after the party was closed.

In order to understand this politics and to gain a wider perspective on its ideological formation, this article suggests focusing closely on the autobiographical writings of PRP leaders Karabekir, Cebesoy and Orbay. ${ }^{8}$ These texts both review a longer span of history than their authors' involvement in the PRP, and reveal the most neglected aspect of their ideological legacy - i.e. an idiosyncratic form of elitist conservative nationalism along with this Unionist legacy. Focusing on these autobiographical writings and their 
inter-textuality as a political site, this analysis throws a different light on the Early Republican opposition politics, and contributes to the literature on conservative thought in Turkey by unearthing an often-neglected thread of conservative imaginary.

When the focus is shifted away from their party-based politics, the liberal tenets of the party, or the kind of active politics Karabekir, Cebesoy and Orbay conducted in the 1920s to their autobiographies, it becomes possible discern a peculiar blend of nationalism and conservatism in their recounting of the past. This shift of focus demonstrates that their conservative nationalism displays significant elements of Edmund Burke's conservatism, ${ }^{9}$ despite their strong Unionist legacy and devotion to the idea of a 'Turkish revolution' (Türk Inkllabi). First, as their autobiographical writings extensively focus on who deserves to lead the post-war political process on behalf of the Turkish nation, the opposition posed by Karabekir, Cebesoy and Orbay maintains the need for a vanguard-like moral leadership of wise statesmen within the larger political elite - which is an essential tenet of Burke's conservatism instead of representing the 'people' against the political center. Second, they articulate the moral traits they ascribe to these leaders, or statesmen, as embodiments of the 'moral character' of the Turkish nation. More than anything else, their autobiographical writings provide extensive descriptions of the moral qualities of both the authors and their political rivals. Karabekir, Cebesoy and Orbay frequently project moral traits they consider as signs of this national character onto each other. They envision themselves as moral servants of the nation and as those who displayed unconditional sacrifice, humility and selflessness. This stands in stark contrast with their political rivals in the texts - i.e. the newly emerging clique of politicians and bureaucrats in Ankara, depicted as unhinged, greedy, corrupt, and incompetent individuals 'surrounding' Mustafa Kemal $\left(\right.$ etraf $\left.^{10}\right)$. This articulation of a moral 'us' vis-à-vis an immoral 'other' resembles another fundamental tenet of Burke's conservatism, his moral scepticism about corruption-prone and power-seeking revolutionary elites. Just like Burke, they see this emerging military-bureaucratic-political elite as a threat to the moral essence of the Turkish society and its organic social transformation into an independent nation, which must be guarded by wise statesmen. ${ }^{11}$

The following section of the article provides a brief contextualization of autobiographical writing in the Early Republican period. The third section consists of an analytical discussion of the literature on conservative thought and politics in post-Independence War Turkey. The fourth section outlines the analytical components of Karabekir, Cebesoy and Orbay's conservative nationalism (elitism, authoritarianism, moralism and skepticism towards the revolutionary clique) and how it diverges from, and yet in the last instance converges with, conservatism. The fifth section unpacks how references to 'moral character' enable them to articulate claims to righteous leadership 
and political legitimacy. The sixth section analyses how 'etraf serves as a narrative trope that imagined an ambivalent 'immoral' (la-ahlaki) or 'corrupt' (fesatçı) political enemy, hijacking the progress of the nation.

\section{Autobiographical narrative as a site of politics in Turkey}

This article focuses exclusively on the autobiographies of Karabekir, Cebesoy and Orbay for three major reasons. First, historically both the public readership of political memoirs and scholarly studies of the Early Republican period highlight Karabekir, Cebesoy and Orbay's lives as 'treasures' of history waiting to be unearthed. These three figures had joined forces with Mustafa Kemal from the start of the war, partaking in most of its decisive moments, military achievements and political crises. Second, these three figures were not only among the leaders of the National Struggle but also led the first opposition party of modern Turkish politics, the PRP, along with Refet Bele and Adnan Adivar. Thus, Karabekir, Cebesoy and Orbay formed a political and military trio for more than a decade. This links to the third reason for this analytical focus, that these three key political figures systematically reference each other in their memoirs and create an inter-textual political space for collective memory making. This inter-textuality could only be seen through a comparative focus on how three close friends frequently mention each other in an attempt to convey their own individual life-stories. This analysis demonstrates that each text rarely makes individual-personal claims about its author's own moral character. Instead, the authors tend to project moral character traits onto each other (and onto other opposition figures), citing each other's experiences, stories and memories. ${ }^{12}$ By constantly invoking each other as 'witnesses' of a past they shared with Mustafa Kemal, they transform individual memory into a politics of collective remembering.

The 'official' account of the events that took place in the immediate aftermath of the First World War and the following decade of political turmoil in Turkey rests upon an autobiographical reflection on past events by Mustafa Kemal in his Great Speech - Nutuk. ${ }^{13}$ In that sense, new histories and historiographies beyond (or complementing) Nutuk have often invoked autobiographical accounts of the leading cadres of the Independence War who founded the first opposition party. ${ }^{14}$ The canonization of Nutuk converged autobiography with history, and personal narrative with truth in the making of modern Turkey. ${ }^{15}$ As a result, the publishing of autobiographical writings by other major leaders of the 1919-1922 Turkish National Struggle (especially those whose narratives diverged from that of Mustafa Kemal) has drawn wide interest throughout the history of the Turkish Republic. ${ }^{16}$

A new wave of memoir publishing started in the aftermath of the establishment of multi-party democracy in 1946. These works included memoirs of leading figures of the late Ottoman Empire and Early Republic published 
posthumously by their families. ${ }^{17}$ Starting in the 1950 s, intellectuals, journalists and political actors made frequent references to Karabekir, Cebesoy and Orbay and cited their memoirs in addressing the 'unrevealed' facts of the post-war Republic. Especially in the 1960s and 1970s, Islamist-conservative intellectual circles and the larger right-wing political imaginary have revered such texts as precious yet repressed sources of an alternative history that is yet to be unearthed. ${ }^{18}$ Similarly, a less conservative strand of popular historians hailed Karabekir, Cebesoy and Orbay as great heroes that suffered from unfortunate circumstances, and as such needed to be given their due. ${ }^{19}$ As part of the Islamist intelligentsia that flourished during the 2000s, several leading right-wing conservative publishing houses ${ }^{20}$ re-published memoirs of opposition figures of the Early Republic. ${ }^{21}$ By late 2010, public debates on TV programs, polemics in newspaper columns and popular history journals ${ }^{22}$ raised this interest (which had been relatively limited to marginalized Islamist circles since the 1970s) to a whole new level of popularity, by representing these texts as major historical sources of truth. ${ }^{23}$

Given this particular historical background of autobiography and memoir publishing in Turkey, and the connections drawn by contemporary conservative historiography with the autobiographies of key political figures of the Early Republic, this analysis of the idiosyncratic forms of conservatism that appear in Karabekir, Orbay and Cebesoy's autobiographical writings sheds light on existing frames of understanding conservative politics both during the Early Republican and later periods. ${ }^{24}$

\section{Early republican conservatism}

An enduring dualist account has dominated studies on conservatism in Turkey: secularist, modernist elite politics and its 'top-down' ideology, against a reactionary conservatism with its political ideology anchored in Anatolian hinterland traditions. Despite variations, majority of the literature has portrayed conservatism as representing the 'people' and 'periphery' against the Republican elites, ${ }^{25}$ or as religious, traditional and 'reactionary' forces that resisted, or could not adapt to, the fast-paced Westernization. ${ }^{26}$ The overemphasis on party politics rests on this sociological outlook of conservatism as a centrifugal force and a background for the rise of Anatolian traditionalist conservatism after the 1940s and 1950s. ${ }^{27}$ These works emphasize deep cleavages between 'the center and the periphery,' strengthening the image of a geographically separated, antithetical and Anatolia-based conservative opposition. ${ }^{28}$

Contemporary conservative scholarship strongly adheres to this centerperiphery framework and analyses the PRP as the earliest challenge posed by the 'people' against the elite-led center. ${ }^{29}$ For instance, Ömer Çaha claims that Turkish liberal-conservatism has a legacy that can be traced 
back to the PRP, Liberal Republican Party (Serbest Cumhuriyet Fırkasi) and Democrat Party. ${ }^{30}$ Other conservative interpretations focus on the PRP leaders' autobiographical writings and frame them as alternative sources of true historical knowledge, claiming that official accounts are misleading and partial. $^{31}$ In this view, Nutuk and other official texts represent the voice of the authoritarian state, whereas dissident memoirs represent the repressed voice of the people. This approach, shared among conservative scholars, maintains an image of the PRP and its leaders as having initiated an intellectual and political legacy of liberal and democratic conservative opposition. ${ }^{32}$

Works by historians Erik J. Zürcher, Feroz Ahmad and Şükrü Hanioğlu, on the other hand, affirm the shared intellectual (Unionist) legacies of both Mustafa Kemal's Republicanism and the PRP's oppositional politics. ${ }^{33}$ Although these works do not specifically engage with conservatism, their claim that founders of the opposition in Early Republican Turkey were in fact part of the shared central elite formation complicate the assumptions that portray the PRP as representing the 'people,' or as external to the political center. These works recuperate the PRP leaders from simplistic images of peripheral reactionaries by underlining the shared military, political and intellectual Unionist backgrounds of Mustafa Kemal and Karabekir, Cebesoy and Orbay. However, they overstate the fact that Karabekir, Cebesoy and Orbay were elite figures with a shared Unionist background. For instance, Zürcher argues that they were part of an intra-elite struggle and that they ended up with a liberal-leaning opposition party in order to sustain a legitimate power competition with Mustafa Kemal. ${ }^{34}$ While this autobiographical analysis affirms that the PRP leaders shared a military-elite nationalist legacy as well as some elements of liberalism, it argues that the moralistic discourse the PRP leaders adopted when writing their autobiographies led to the emergence of an idiosyncratic blend of conservatism and nationalism. Through carefully attending to their moralizing discourse, which rests on intertextual politics, this article unearths aspects of their political position that have so far been ignored in the literature.

This article specifically builds on and contributes to a recent thread of studies on Early Republican and single-party era conservative intellectuals that were not part of the political opposition. These studies offer fresh perspectives on the Early Republic and complicate dualistic portrayals of conservatism as a peripheral reaction against the Kemalist modernist-nationalism of an emerging political center. ${ }^{35}$ Nazım İrem's studies on intellectuals blending Kemalist modernism with conservative tradition challenges the dominant trend in Turkish historiography of characterizing the Kemalist Revolution as 'a zero-sum game between secular-modernist Kemalists in action and religiously oriented anti-modernists in reaction. ${ }^{36}$ However, his focus is restricted to a subservient intellectual elite circle at the service of the Kemalist bureaucratic hegemony and single-party rule. Christine Philliou's work on 
Refik Halit Karay uncovers a unique elite position that is neither in the political center, nor in the reactionary periphery. ${ }^{37}$ Alexander E. Balistreri's work on Kadirbeyoğlu Zeki Bey, the only MP who voted against the abolition of the caliphate, similarly complicates the dualist account of conservatism, affirming that a conservative elite was active in the center. ${ }^{38}$

Based on Russell Kirk's readings of Edmund Burke's conservatism, ${ }^{39}$ this article claims that Karabekir, Cebesoy and Orbay's portrayals of their own political opposition have conservative elements, despite their revolutionaryunionist political legacy and endorsement of some liberal ideas. Russell Kirk underscores the significance of a strong commitment to a transcendent moral order and its incarnation in the world through moral values as the most important trait of conservatism. ${ }^{40}$ If Kirk's readings of Burke were to be followed, despite their differences from other tenets of classical conservatism, Karabekir, Cebesoy and Orbay still qualify as conservatives. While emphases on sacrifice, selflessness and humility could be viewed in many other forms of non-conservative nationalism in Turkey and globally, what makes them conservative in the larger Burkean sense is their moralist discourse, their belief in a transcendent moral order - although they see this order as a process oriented towards the future, unlike the classical conservative glorification of the past. This moralizing discourse imagines a continuous threat of moral corruption $\left(\right.$ fesat $\left.^{41}\right)$ against which the moral substance and social fabric of the nation have to be preserved, depoliticizing political rivalries. This heavily evokes Kirk's claim that 'political problems, at bottom, are religious and moral problems.' 42

This article argues that the autobiographies' framing of political problems in moral terms consistently adheres to a similar conceptualization of politics, even though Karabekir, Cebesoy and Orbay do not explicitly adhere to conservatism as an ideology. Burke espouses a moral skepticism towards revolutionary elites as unhinged, greedy and corrupt individuals who undermined a moral order, and argue that political power should instead rest with moral and wise statesmen who would wield and control social change responsibly. Similar to Burke, Karabekir, Cebesoy and Orbay prioritize morality as a matter of temperament and character, posing themselves and their political position, as moral counterparts of a corrupt revolutionary elite. ${ }^{43}$ They believe in a moral order that is threatened by an unhinged-greedy (muhteris) post-revolutionary cadre, which needs to be kept in check by the guardianship of wise and moral statesmen - a select few among those who embodied the national moral character of the Turkish revolution.

This theoretical analysis indicates that the conservative nationalism analyzed here is not a specific doctrine with its own political constituency within society. It is rather a moralistic vision of a national order that is gradually actualizing itself through history, but has to be protected against the 'corrupt' excesses of an unhinged revolutionary elite. Moralization of the 
political discourse counter-poses compatriots with a national character against those who lack it, ascribing a naturalized right for a select few to serve their nation. Unearthing elements of such an elitist discourse in Karabekir, Cebesoy and Orbay's writings decouples their position from the historiography of conservative scholars, which overstates the liberalism or popular democracy of the PRP.

\section{Moral elitism in Karabekir, Cebesoy and Orbay's conservative nationalism}

Karabekir, Cebesoy and Orbay primarily portray their individual stories as the maturation of selfless nationalists who served the nation with their comrades during the late Ottoman period and the National Struggle and afterwards. While the emphasis on sacrificial comradeship could be dismissed at first sight as typical popular nationalist rhetoric of the time, this article shows how multiple nationalist tropes produce peculiar moralizing discourses that ultimately reclaim a lost authority over the Republic and the new nationstate. Analyzing the PRP's nationalism requires a rather broad description of the term, which identifies the origins of nationalism within Young Ottoman and later Young Turk discourses that articulated 'motherland,' 'blood' and 'religion' as the three fundamental tenets of Turkish nationalism. ${ }^{44}$ Although it was mainly the Early Republican leadership and the new modern nation-state that institutionalized and canonized 'Turk-ness' as a national identity, the history of Turkish nationalism goes back to the late Ottoman Empire. ${ }^{45}$ Thus, many oppositional figures of the Early Republic including the figures discussed in this article were situated within this Young Turk discourse of nationalism.

The autobiographical politics of Karabekir, Cebesoy and Orbay extensively builds on moralizing discourses contrasting their own heroic achievements against the rise of a circle of military-bureaucratic elites - etraf - surrounding Mustafa Kemal after the Independence War. The authors incessantly document the rise of 'corrupt' and inept individuals at the expense of those sacrificial comrades. They insist that whoever displayed the national character and thus sacrificially served in the war should have ruled the cadres of the new polity in principle.

Karabekir for instance provides extensive documentation about his objections to the promotion after 1921 of army officers that he did not deem worthy. His objections increase especially after 1923, when the issue of promotion became increasingly divisive. Orbay provides a similar description of the new bureaucratic-political clientele in Ankara when he returned from exile in Malta in 1921. His memoirs from 1921 to the 1930s abound with observations on the 'dangerous' figures and etraf, portraying these circles as not having partaken in the dutifulness of serving in the war along 
with Mustafa Kemal. Cebesoy similarly notes that 'all kinds of people' had rushed into and hijacked Ankara with their 'avarice/greed' (ihtiras) and 'domination mentality' (tahakküm zihniyeti) as early as 1920 - explaining the political pressure that caused Mustafa Kemal to 'unwillingly' appoint Cebesoy as ambassador to Moscow, removing Cebesoy from the political scene for a while

I had heard during those days that a [sense of] distrust and insecurity befell the social circles of Ankara, and that mentalities and ideas of personal government were becoming predominant, but I had refused to believe any of it. (...) no. doubt, the flocking of all kinds of people to Ankara had also caused this [situation]. The unhinged avarice and greed that was emerging among certain people was naturally destined to pull the new administration towards a mentality of personal government. (...) It was becoming clear that the domination mentality was gaining prevalence. ${ }^{46}$

Karabekir, Cebesoy and Orbay were part of the same Unionist military-elite social milieu, ${ }^{47}$ with a preference for the top-down resolution of political problems by a like-minded military-bureaucratic elite. And they almost never justify their actions in their writings as giving voice to the 'Anatolian people,' or proposing an alternative ideology on their behalf - apart from abstract references to how they are serving their nation. Hence, it is not surprising to come across dismissive vanguardist-elitist remarks about the 'people' in their autobiographical writings. Karabekir wrote:

The foundation lays underground. Only experts know about the integrity and longevity of a building, because they have a grasp of the foundation. The people can only pass judgement by looking at the polish on the visible façade. They cannot see what is going to fall off and when. ${ }^{48}$

This quotation is a good example of the elitist discourse that views 'people' (halk) as focusing on appearances and incapable of understanding the essences of history, as opposed to those experts (mütehassislar) who are able to do so.

The authors claim that they established the first opposition party in order to preserve the spirit of the Turkish revolution. Even though the official party program included elements of political and economic liberalism, their autobiographies neither express an interest in pluralizing the political space nor any pride in partaking in the first experiments of the multi-party system. The authors refrain from portraying the PRP as an ideology-driven party. They disregard the political and ideological nature of their own discontent with the RPP, and retrospectively portray their opposition as a moral duty to reaffirm the spirit of the nation and the Republic. As such, they view themselves as vanguards of the revolution (Türk İnkılabl) and the Republic:

We were going to do our best to prevent the falling of our regime, the Republic, into the hands of individuals or cliques. ${ }^{49}$ 
They similarly described their resignation from the RPP and establishment of a new party not as a result of their admiration for multi-party politics or democratic institutions but in terms of a moral responsibility to preserve and represent the Turkish revolution against the danger posed by etraf. They are deeply skeptical of (what they viewed as) the unhinged and unmoderated radical reformism of the RPP, seeing it as driven by an avid greed for political power and domination. In that sense, for them, etraf and the RPP under its influence did not represent the Turkish nation at all. The following quotations from Cebesoy's political memoirs clearly lay out how they see the difference between the RPP and the PRP in moral instead of political terms. Both quotations explain why they established a new political party and what they deemed problematic about the existing ruling party:

We [founders of the PRP] were chosen [at first] as representatives of the original [Committee for] Defence of Rights (Müdafaa-i Hukuk). It wasn't us who deviated from the principles of Defence of Rights, it was members of [the RPP]. ${ }^{50}$

The doors of the party [RPP] were open to all citizens, irrespective of their personal convictions. The party was especially under the control of mideciler [stomach-fillers]. Of course, there were also many citizens among [party members] that deserved respect. (...) Those who were acting according to their own independent opinions had remained within the party with the hope that there might eventually emerge wider inclinations to maintain unity and stability. ${ }^{51}$

Ironically, the reference to the 'openness' of the RPP to all sorts of citizens has a productive ambiguity for Cebesoy's discourse: it both refers to an earlier moment of political equality which was betrayed by those who hegemonized the party, and to the promotion of unworthy individuals into the RPP's higher ranks, which made the party weak. There were also 'şayan-1 hürmet' (worthy individuals), who resisted separation until it became impossible for them to operate in the existing party. And these people, in Cebesoy's view, were the real proponents of the national struggle and the principles that it was based upon, while their rivals were simply deviating from these principles.

The notion of the 'Republic' is often contrasted in the autobiographies, as an abstract principle, with domination and greed for power - again in moral terms that separate the author from those with a character weakness to seek power, or to become subservient to those who have power. The 'us' versus 'them' discourse is straightforward and repetitive especially after 1924, associating the RPP with a clique of 'stomach-fillers,' while portraying the PRP as a sincere attempt to keep the Turkish revolution on track. The following quotation from Karabekir is an example of how the authors endorsed the Republic as a value to be associated with its 'real' proponents - not the hypocritical and fake Republicans: 
In my opinion, the most important thing is to tell the wider public that the Republic is a good thing and to keep the Republic [together] with the true Republicans. Not with hypocrites. Hypocrites are those miserable [people] who just keep on clapping [in support], whatever the name of the regime. ${ }^{52}$

In that sense, Cebesoy and Orbay joins Karabekir in claiming that they were the real proponents, if not owners, of the Republic - drawing clear lines of separation between 'us' and 'them.' The moral aspect of this separation is particularly significant, since it reserves political authority for the authors by denying the worthiness of their rivals as proponents of the Republic, instead portraying them as weak and hypocritical.

What is called conservative nationalism here is qualitatively different from some of the basic pillars of conservative thought and politics: the PRP leaders were not counter-revolutionaries or anti-reformists. They did not have abstract allusions to an 'ancient regime' that needed to be guarded. Their support for reformist ideas of progress and the Turkish revolution distinguish them from classical conservatism. In other words, they invert the temporality of the moral substance of history that is typical of classical conservatism: they do not consider history as a moral degeneration from a glorious past, as it is in most classical conservative ideologies but a teleological maturing of a nation's moral and rational development into the future - very similar to the ideals of the German Enlightenment.

Zürcher claims that their party program did not correspond to classical versions of nineteenth or twentieth century conservatism. He refers to Frederick Frey's analysis that many revolutions or revolutionary movements of the same period had their own evolutionist-gradualist wings or intellectual circles ('post-independence conservatives') that ended up in opposition to a Jacobin hardliner wing - what Frey called 'ardent nationalists. ${ }^{53} \mathrm{He}$ argues that the PRP was such a liberal and evolutionist wing of a revolutionary elite, aspiring for a social contract-based political legitimacy, 'who see the achievement of independence as the fulfillment of their ambitions and reject further radical social and cultural change. ${ }^{54}$ As for the party, he claims:

its philosophical basis clearly was to be found in liberalism, not conservatism and there are no traces of monarchism or religious reaction anywhere. (...) This was also (belatedly) recognized by İsmet İnönü ${ }^{55}$ [who wrote in 1963] that the party had never described itself as conservative and that its leaders were in fact 'progressive and reformist people' (ileri fikirli ve ıslahatçı insanlar). They were. ${ }^{56}$

This paper does not reject the idea that the PRP followed an overtly liberal party program that displayed elements of a liberal-social contractarian ideology. However, it is claimed that the overemphasis on this program obscures the complex layers of its leaders' oppositional politics, which continued evolving even after the party was closed. 


\section{“Moral character' and the Independence War}

Moralizing discourses on character pervade both the recounting of the National Struggle and the Early Republican period. The autobiographies do not follow a linear temporal sequence. Heroic scenes and sacrifices during the National Struggle frequently pop up during the recounting of the oppositional politics in the aftermath of the Republic. This section shows how references to the National Struggle are cited as proof of moral character. Despite variations in tone, subjects and perspectives, all three authors emphasize how dutiful and self-sacrificial individuals that had a significant role in the National Struggle were being sidelined in favor of those who had barely made any contribution. They often qualify this line of separation with respect to character traits and dispositions that were displayed during the National Struggle.

In Nutuk, Mustafa Kemal provided a self-centered narrative that claimed the National Struggle would have been at risk without his exceptional understanding of existing situations, foresight and last-minute interventions in crises. Mustafa Kemal also portrayed Karabekir, Cebesoy, Orbay and many other key figures of the Independence War as prone to errors in judgment, occasionally imprudent, politically timid or lacking the will to execute planned or pre-set courses of action against the odds. However, Karabekir, Cebesoy and Orbay refrain from overtly responding to such portrayals and incriminatory accusations in Nutuk or among pro-government circles. With the exception of Karabekir's Istiklal Harbimizin Esasları (Fundamentals of Our Independence War), their autobiographies are not written in a confrontational tone.

Orbay's memoirs are full of descriptions of scenes in which Mustafa Kemal and Orbay hugged each other in tears of joy or grief, and how worked together day and night, along with devoted others like Cebesoy and Karabekir, as well as Hüsrev Pash, a (Gerede) and Refet Pasha (Bele). The following quote from Orbay's account of when he and Mustafa Kemal were in Erzurum in 1919, immediately before the Erzurum Congress and right after Mustafa Kemal resigned from his military post in order to claim leadership of the independence movement, is such a portrayal of sacrifice. It starts from the moment when the two were informed that Karabekir was about to visit them. Karabekir presents his allegiance to Mustafa Kemal with full support and respect, which emotionally strikes Mustafa Kemal. Orbay details how Mustafa Kemal, in tears, hugged Karabekir to express his joy and gratitude:

At that moment, I should admit, I absolutely could not estimate that [Karabekir], with such an unprecedented selfless sacrifice and humble benevolence that I had neither observed nor heard of throughout my military life, was about to create such a memorably vivid historic scene for future generations to remember that they would visualize as if they had seen it with their own eyes. ${ }^{57}$ 
Orbay interpreted Karabekir's recognition of Mustafa Kemal's leadership as characterized by exceptional sacrifice, selflessness and humility, and as a distinct act of patriotism which should form a historical model for the future generations. Such depictions of character and the incessant tethering to the Independence War in the narrative serve as reminders that Karabekir and his fellows shared a moral disposition to serve the nation unconditionally. Even though the main actor in Orbay's story was initially Mustafa Kemal, its conclusion ultimately marks Karabekir as a genuine and devout soldier, who prioritized winning the National Struggle over every other concern.

As pointed out before, these autobiographies were not written in a perfect linear temporality. Within critical discussions of the Republican era, the earlier period of the Independence War frequently appears as a recurrent background to demonstrate how a select few bears the character and disposition to resist corrupt power relations. The authors highlight seciye and strength of character with references to their sacrifices during the war, as well as to other instances during pre- and post-war periods, often in the same paragraph. The word seciye, translated as natural moral character, is interesting because in Ottoman Turkish it assumes the existence of a superior character by birth. Thus, those who proved their high natural moral character by leading the Independence War were considered to have a natural disposition to lead their country and conduct political reforms.

Cebesoy clearly distinguishes between people who hold a moral character and those who do not. He associates moral character with being impervious to unhinged greed, corruption and subservience to others. Accordingly, in his view, those who lack that character become part of corrupt relations of power and domination. It is possible to interpret this moral separation as questioning the political legitimacy of those without such a moral character to influence how the Turkish revolution was to be realized and implemented. The following quote from Cebesoy similarly highlights the centrality of seciye in bringing comrades together under the flagship of the PRP:

[Our aim] simply consisted of not trying to gain strength by compromising on our opinions, and [instead] gathering those of strong personal convictions and moral character under the banner of the [spirit of] true renovation and national will. ${ }^{58}$

He clearly stresses that the leaders of the PRP cared less about strengthening their parties' power of representation with more members of parliament, but instead tried to bring together those who had robust convictions (kanaat) and character (seciye). As these quotations reveal, the emphasis on prioritizing individuals with specific moral character traits is central to the fine-tuned elitism. They contrast with the RPP's policy to keep its doors open to 'all kinds of people. ${ }^{59}$ 
These references to the sacrificial fellow comrades during the National Struggle reserve a space for a select few to act like guardians on behalf of their nation. They portray an elite group of vanguards that are tasked with the moral duty to preserve and maintain the Turkish revolution's connection to the legacy of the Independence War. The next section deals with how this sacrificial vanguard discourse juxtaposes with the newly emerging militarybureaucratic elite of the post-war Republican capital: etraf.

\section{The moral threat posed by Etraf}

After the Lausanne proceedings (1923), due to increasingly critical and polemical stances Karabekir, Cebesoy and Orbay took in the parliament towards a series of governments led by İsmet İnönü, their relationship with the RPP and the political authority of Mustafa Kemal became increasingly strained. In 1924, their de facto elimination from power led them to establish the first opposition party, the PRP. Following a religious insurgency led by Kurdish leaders in Eastern Anatolia (Sheikh Said rebellion) and subsequent involvement of the army, the government closed down the PRP and introduced the 'Law on the Maintenance of Order' (Takrir-i Sükun Kanunu) in 1925. A year after the insurgency, an assassination attempt on Mustafa Kemal caused a massive wave of tribunals. All opposition politicians and dissident figures were arrested and put on trial. Karabekir, Cebesoy and Orbay were accused of plotting to overthrow the government and assassinate Mustafa Kemal. $^{60}$

According to Karabekir, Cebesoy and Orbay, the establishment of extraordinary Independence Tribunals and many other political developments of the time revealed the lack of moral character and integrity among the state apparatus. The typical incarnation of this lack of integrity and selfishness was an abstract allusion to a set of politicians, bureaucrats, artists and intellectuals that surrounded Mustafa Kemal - etraf. Members of this clique, some of the rising political figures within the RPP during the late 1920s, are all portrayed in the autobiographies as lacking the qualities of national character, moral integrity and patriotic feelings. Each of the three has a different take on how to conceptualize etraf. For Karabekir, etraf is a more generalized 'immoral' milieu of selfish and incompetent newcomers that emerged in the political scene after 1923. Cebesoy views etraf as bureaucratic corruption, a product of self-interested people with 'tendencies for domination.' And for Orbay, etraf is a sinister set of political agents with secret agendas, who legitimized their influence by getting closer and closer to Mustafa Kemal. In his view, these agents were the enduring legacy of corrupt and unlawful ways to conduct politics, especially komitacılık. ${ }^{61}$

Orbay frames the political actors around Mustafa Kemal and in the broader ranks of the nascent bureaucracy by referring to komitacılık - extreme 
political tactics that involve resort to conspiracies and assassinations through small-armed groups. He considers komitacilik to be a remnant of the violent and militaristic political culture of the Balkans-infused Committee for Union and Progress period. His comments on komitacilik expresses the concern that such old habits continued to live among many figures of the new political scene in Ankara, leading them to resort to such means to neutralize their opponents - particularly emerging figures of the opposition. ${ }^{62} \mathrm{He}$ also refers to a series of assassination attempts that target him, and to the secret police that watched his moves for years, as proof that this unfortunate political custom was yet to be eradicated from the political scene of Ankara. He further claims that dark and mysterious figures around Mustafa Kemal continue resorting to such means for decades after 1922. ${ }^{63}$ Both Cebesoy and Orbay draw a clear line between Mustafa Kemal and those who influenced him, however. By neither directly blaming Mustafa Kemal nor mentioning him in any negative way when depicting tense political scenes, they avoid confrontation and affirm their loyalty to the well-established friendship between them.

In comparison to Orbay, Cebesoy is more careful in distinguishing Mustafa Kemal, as the President, from the cabinet and its political associates. Cebesoy describes how Mustafa Kemal was surrounded by the 'greedy' and 'resentful' etraf:

I intimately knew that my brothers continued to harbour respect, confidence and trust towards [Mustafa Kemal]. It was perfectly reasonable that a person, who felt a mutual sentiment with someone, would try to maintain this sentiment among others. Therefore, I had always looked forward to an opportunity [to do something] with this particular longing. However, I knew that it was not an easy task to overcome the greed and resentments of those extremists that had surrounded [Mustafa Kemal]. Nonetheless, I had never quit and continued trying with fervor and aspiration. ${ }^{64}$

Cebesoy locates the problem (the reason why he and his friends were disconnected from Mustafa Kemal) in the influence of etraf, composed of actors motivated by avidity. He maintains that his friends held similar respect and trust for Mustafa Kemal, and describes himself as an unyielding peacemaker between Mustafa Kemal and his friends who struggled to overcome the blockage of etraf, keeping alive the spirit of the brotherhood of comrades that led the Independence War.

Karabekir, on the other hand, does include Mustafa Kemal within the 'decadent' cultural landscape of the new Republic. He frequently depicts unpleasant scenes in which Mustafa Kemal was involved, though he avoids statements that target Mustafa Kemal directly. Many of his depictions involve Mustafa Kemal in 'immoral' (la-ahlaki) settings or merely situated within an 'immoral' etraf. Karabekir expresses utter discomfort with the long, pre-prepared tributes (medhiye) for Mustafa Kemal during the first 
commemoration of 30 August, the Victory Day (Zafer Bayrami), commemorating one of the most decisive battles in the National Struggle:

August 30, 1924, Saturday - We arrived by 12, noon. Trains had arrived from Ankara and İstanbul. Aide Salih called [me] to the train car [reserved for] Gazi [Mustafa Kemal]. [It was] in a state of tavern, irreligious and immoral. I discussed [the state] of the country. He said [the issues I mentioned] were indeed requisite. The ceremony occurred later. Pre-prepared tributes were recited. A set of subservient [officers] lauded Gazi on behalf of the press, academics, lawyers, etc. Erkan-ı Harbiye Reisi [chief of staff] mentioned the National Struggle. But again, no. reference to the Eastern front. This ceremony was disorderly. Officers were rude to guests. A young journalist, called Nüzhet Hâşim, was hypocritically making speeches on behalf of academics and teachers, but one could hear sentences like academics were burdens. On behalf of lawyers, Muhittin Baha (former Bursa MP) was lauding Gazi and accusing the nation of being ungrateful! On our return to the train, I bitterly protested these hypocrisies to Fevzi Pasha, but [I wish I] had spelled out the truth, or at least a part of it. Even Gazi, at the train, for a moment, said, 'It will be whatever the nation wants!' After my departure, [as I heard later] he told other commanders that: 'Nation, and all that - these are nothing but empty talk.' ${ }^{65}$ (Italicized emphasis is mine.)

The quote is one of the most vivid descriptions of Karabekir's discontent with the growing 'decadence' within the changing public representations of political power and among etraf. Karabekir complains that his successes in the Eastern front were not mentioned within these long praises, and also that the day was celebrated in an 'irreligious' (la-dini) and 'immoral' (la-ahlaki) style. This is one of many instances in which Karabekir targeted the RPP leaders for denigrating him (or fabricating lies about him) to steal his and his brothers' moral dignity. ${ }^{66}$ In the abrupt last sentence, he claims that he later heard that Mustafa Kemal had said, 'Nation, and all that - these are nothing but empty talk.' While not providing any context or detail, the ambiguity and abruptness of the way he quotes Mustafa Kemal calls into question whether and how Mustafa Kemal, claiming to embody and protect the national will, actually respected and valued the 'Turkish nation.' It is also unclear whether Karabekir meant that Mustafa Kemal himself was also hypocritical like etraf, since he spoke differently about the 'nation' for different audiences.

\section{Conclusion}

Despite significant differences in framework, the way Zürcher explains PRP leaders' liberal aversions to the statist official ideology converges with conservative scholars' celebratory analysis of them as voices of the people. Attention to their moralizing discourse, and its elitist and vanguardist aspects offers an account of Karabekir, Cebesoy and Orbay's politics that significantly differs 
from the historiography of conservative scholars, or from the historiography of works that completely ignore the conservative elements within their politics. Conservative scholars associate the political legacy of these three authors with a liberal-conservative traditionalism on behalf of Anatolian populations. Conversely, the other major thread of literature on the PRP leaders ignores the conservative elements within their politics by overstating their Unionist legacies or the elements of liberalism or popular democracy in their party program. This article maintains that analyzing Karabekir, Cebesoy and Orbay's autobiographical writings as the bedrock of this political space offers a correction to scholarly overemphasis on PRP party politics and provides a fresh perspective into their wider opposition politics.

The analysis offered in this article demonstrates that Karabekir, Cebesoy and Orbay's conservatism did not seek to voice the conservative sensibilities of a repressed people against a secular-reformist nationalist state. Despite the emphases on freedom, democracy and liberalism in the PRP party program, autobiographies reveal an endorsement of an elitist moral guardianship by select soldier elites - who fulfill the function of Burke's wise and moral statesmen, tasked with neutralizing the threat posed by the excesses of an unhinged revolutionary elite. This focus on vanguardist-elitist conservative nationalism calls for further research on Early Republican history and conservative politics in Turkey. The elitist conservative nationalism of the first oppositional party leaders offers a reinterpretation of Early Republican history that goes beyond the dualist frames of modernism vs. traditionalism, secularism vs. religiousreactionarism or center vs. periphery.

Morality is central to the articulation of a 'conservative nationalist' political position in universalist terms, claiming to represent the whole nation - i.e. not particular factions, ideologies, social groups, etc. The recognition of the central role of morality in the autobiographies situates them within the tradition of Edmund Burke's conservatism. Their moralizing discourses reframe a complex set of political disagreements and ideological debates of the time in terms of character, disposition and temperament - those who are worthy of representing and governing the nation, vs. those who are not. Furthermore, these moralizing discourses also obscure intra-elite disagreements and competition for power. The discourse of 'us' vs. 'them' homogenizes the diversity of political voices within the Early Republic and reduces the political field to the duality of betrayed patriotic heroes vs. unworthy bureaucrats that hijacked the Turkish revolution. While these moralizing discourses depoliticize various issues of the time in discourse, it also ironically creates a forceful political space in practice that calls the reader to read history from the author's perspective and act on behalf of the author - to protect the moral legacy of the Turkish revolution against threats.

Karabekir's epigraph to his Our War of Independence (Ístiklal Harbimiz) epitomizes the political significance of writing personal narratives on the 
history of the Independence War: 'We waged the National Struggle. If its actors do not write [about it], [then] its history becomes a fairy tale. ${ }^{67}$ In this sense, their writings pose an idiosyncratic political site that calls future generations to actively remember and re-evaluate history in a way that does more than demand political legitimacy and recognition of service - it creates its own political ideology with a moral-universalist claim to represent a whole nation. As the continuous reprinting of these autobiographies and their popularity among conservative scholars and intelligentsia reveal, their call has been taken seriously since then, and their autobiographies have had an enduring popularity among both conservative, Islamist and center-right political constituencies, as well as their intelligentsia. Autobiographies in that sense are political sites that are continuously re-appropriated by new generations who problematize the history of the Early Republic - especially the controversial issues such as the Lausanne Proceedings and Independence Tribunals.

\section{Notes}

1. For the political history of the first opposition party of the Turkish Republic, see Zürcher, Political Opposition; Ahmad, "The Republican People’s Party”; Ateş, Türkiye Cumhuriyeti'nin Kuruluşu; Yeşil, Türkiye Cumhuriyeti'nde İlk Teşkilath Muhalefet Hareketi. For the history of elite politics and political opposition parties in Turkey, see Frey, The Turkish Political Elite; Zürcher, The Young Turk Legacy; Rustow, Political parties in Turkey; Heper and Sayar1, Political Leaders; Landau and Heper, Political Parties.

2. Established in January 1923, the Republican People's Party was initially called the 'People's Party' (Halk Firkası).

3. I will refer to Mustafa Kemal Atatürk as Mustafa Kemal, since he was granted the surname 'Atatürk' only after 1934, while the other three were already known by their surnames during the time.

4. Karabekir, Cebesoy and Orbay were accused of involvement with an assassination attempt against Mustafa Kemal and were put on 'Independence tribunal' trials for conspiracy and treason (1926). Karabekir and Cebesoy were acquitted, while Orbay's case couldn't be resolved since he was abroad. He remained in exile for 10 years and was eventually acquitted in 1940. For detailed historical analyses, see, Zürcher, "Were the Progressives Conservative?"; Zürcher, "Young Turk Memoirs"; Ahmad, “The Republican People's Party”; for accounts by early popular historians, see Erman, İzmir Suikastl; Kandemir, İzmir Suikastlnın İçüzü; for accounts by contemporary popular historians and journalists, see Mumcu, Kazım Karabekir Anlatıyor; Armağan, Paşaların Hesaplaşması; Yıldız, Küskün Paşalar; Gürler, Paşaların Gözüyle Milli Mücadele.

5. This article focuses exclusively on the core cadre of the PRP leaders and examines how they produced a political narrative of 'opposition' through their recollections of Early Republican history. There are a few other military leaders (like Fevzi Çakmak or Refet Bele) who constituted the leading cadre of the National Struggle under the leadership of Mustafa Kemal, as well as İsmet İnönü (Mustafa Kemal's closest associate and successor to presidency). Refet Bele 
never published his autobiographic works, while Adnan Adıvar was not among the key military figures of the National Struggle, and finally Fevzi Çakmak was not part of the PRP and only left daily notes which did not form an autobiographical narrative.

6. I follow a recent line of works in autobiography studies that criticize clear-cut separations between memoirs and autobiographies, and introduce hybrid terms like 'autobiographical writing', 'life-writing' or 'life-narratives,' in order to bend the law of genre in favour of a broader horizon that acknowledges more diverse forms of self-narratives on life Hunsacker, Autobiography and National Identity; Moore-Gilbert, Postcolonial Life-Writing; Smith and Watson, Reading Autobiography.

7. The main proponent of this view is Erik Zürcher; for detailed analyses on this issue, see his "Were the Progressives Conservative?"

8. Following recent autobiographical and memoir studies, I bracket questions of intentionality and verifiability, and instead focus on autobiographic representations of oneself and others in the text - which correspond to articulations of respective political positions. Hence, I do not treat these texts as alternative historical sources to offer a new historical re-reading of the history of the Early Republic. Instead, I treat them as a political site to articulate an ideological position and to naturalize an elitist claim to political authority in moral terms. For the political dimensions of self-presentation in life-narratives, see Anderson, Autobiography; Smith and Watson, De-colonizing the Subject; Whitlock, Postcolonial Life Narrative.

9. Burke, Reflections on the Revolution in France; for my interpretations of Burke, I follow Kirk, "Burke and the Principle of Order," and the analysis provided by Feulner, "The Roots of Modern Conservative Thought."

10. The word 'etraf means 'surrounding social circle' and in the Early Republican Turkish context it is used to refer to the elite circle around Mustafa Kemal.

11. Unlike classical conservatism's scepticism for change from a past ancient regime to future degeneration, they think reforms are for the good of the society. However, unlike revolutionaries, they attribute a moral order and a sense of teleology to the Turkish revolution, seeing it as a process whereby the moral substance of a nation is gradually being realized. And they consider the revolutionary elite as corrupt individuals against which the process of the realization of this moral order should be protected.

12. These texts are generally retrospectively reworked notes and memoirs from the 1918-1926 period. They were written (or re-organized) during the oftenchaotic period of the establishment of the Republic in the late 1920s and 1930 s - i.e. after the authors had a dramatic fallout with Mustafa Kemal. Karabekir, Cebesoy and Orbay had been keeping daily notes as part of a common social custom of the educated elite in Istanbul since their early youth.

13. The 'Speech' (Nutuk) was read by Mustafa Kemal in the second congress of the governing People's Party in 1927 (Göçek, "Defining the Parameters”; Zürcher, Turkey: A Modern History, 175). Covering the series of events before, during and after the National Struggle, Nutuk has been widely regarded as the sole historical source of the period between 1919 and 1927. Mustafa Kemal delivered Nutuk in six consecutive days in the Turkish parliament in 1927, based on his recollections of the National Struggle, as well as on a plethora of historical documents. This made him the first to publicly construct a history of the emergence of the Turkish nation as an independent nation-state, and has remained 
part of the officially sanctioned history of modern Turkey. Although there is a wide range of military figures targeted by Mustafa Kemal in Nutuk, Karabekir, Orbay and (to a lesser extent) Cebesoy were the most visible due to their close association with Mustafa Kemal during the war. As a result, their memoirs and autobiographies are popularly viewed in Turkey as 'controversial responses' to Nutuk, and there is an ongoing politics of their publishing about what their accounts represent against the 'official history thesis' (Zürcher, "Young Turk Memoirs"; Adak "National Myths and Self-Na(rra)tions," "Who is Afraid of Dr. Riza Nur's Autobiography?”; Parla, Türkiye’de Siyasal Kültürün Resmî Kaynaklari, 1-2-3; Ahmad, The Making of Modern Turkey, 51-71; Lewis, The Emergence of Modern Turkey, 242-3; Poulton, Top Hat, Grey Wolf and Crescent, 878, 200; Zürcher, Turkey: A Modern History, 183; Alaranta, "Mustafa Kemal Atatürk's Six-Day Speech”; Gürpınar, "The Politics of Memoirs and MemoirPublishing").

14. Memoir-writing as a practice started to become popular among educated cadres in the late Ottoman Empire. The rise of autobiographical writing by the educated political and intellectual elite reveals the emergence of new political actors cognizant of their own central position as 'historical subjects.' For an overview of this history of memoir-writing in modern Turkey, see Gürpınar, "The Politics of Memoirs and Memoir-Publishing."

15. Ersanlı, İktidar ve Tarih; Kaplan, Türkiye'de Milli Eğitim İdeolojisi; Adak, "National Myths"; Alaranta, "Mustafa Kemal Atatürk's Six Day Speech."

16. Adak, "National Myths and Self-Na(rra)tions".

17. Erman, İzmir Suikastı ve İstiklâl Mahkemeleri; Kandemir, İzmir Suikastının İcyüzü; Gürpınar, "The Politics of Memoirs and Memoir-Publishing”; Gürler, Paşaların Gözüyle Millî Mücadele, 13-23. Newspapers and magazines were replete with memoir serials by prominent soldiers and politicians who had witnessed the transition from Empire to Republic. Cebesoy's and Orbay's memoirs were first published in these decades (between 1952 and 1965). Karabekir's İstiklal Harbimiz ('Our National Struggle') was released in 1960 (after its initial publication and almost immediate ban by the regime in 1933), and it shared a similar narrative genre with Nutuk for its copious use of historical documents.

18. For the popular historians and their interest in these texts, see, Özcan, Türkiye'de Popular Tarihçilik: 1908-1960.

19. Kandemir, Hâtıraları ve Söyleyemedikleri ile Rauf Orbay; İnam, Rauf Bey; Ertürk, İki Devrin Perde Arkasi; Kutay, Osmanlidan Cumhuriyet'e; Üç Devirde Bir Adam.

20. The most major among these publishers are Emre, Temel, Dergah and Timaş.

21. Similar to the 1950 s and 1960 s, new editions of these memoirs easily still stir a heated public debate about their revelations: previously unarticulated disapprovals, disappointments, or critiques of past policies and prominent figures.

22. Derin Tarih and Popüler Tarih are the most popular among these journals.

23. The popular conservative researcher Mustafa Armağan's views are prominent examples of the Islamic-conservative imaginary of a binary of 'truth vs. lie' that frames popular conceptions about Nutuk and other autobiographies. In his books and newspaper columns, he frequently portrays Nutuk as an overrated book with mistakes and weaknesses. Instead, he suggests that opposition figures of the time, such as Karabekir and Orbay, are more 'worth listening to,' if one wants to understand the truths about that period. Armağan, Paşaların 
Hesaplaşması. For more conservative or Islamist appeals to these texts against Nutuk, see Bahadıroğlu, Osmanlı Demokrasisinden Türkiye Cumhuriyetine; Yıldız, Küskün Paşalar.

24. In popular culture, when these writings started to be publicized for the first time as serials in newspapers during the transition to the multi-party period, i.e. from 1946 to 1970, they were admired and referenced as icons of selfless Turkish nationalism. In particular, centre-right media organs, such as Tarih Dünyası (World of History) and Tercüman daily newspaper, among others, heavily supported their circulation, while popular historians of the time such as Feridun Kandemir and Cemal Kutay passionately celebrated these texts for their historical value as priceless sources. Although these memoirs started to be published several times after the 1940s, conservative public intellectuals and popular historians still celebrate the new editions of these memoirs as sensational scandalous unmasking of official Kemalist ideology.

25. Aktay, "İslamcılıktaki Muhafazakar Bakiye"; Akdoğan, Muhafazakar Demokrasi; Çaha, Dört Akım Dört Siyaset; Çiğdem, "Muhafazakârlık Üzerine"; Mardin, Din ve İdeoloji; Ögün, “Türk Muhafazakârlığının Kültürel ve Politik Kökleri”; Yavuz, Modernleşen Müslümanlar.

26. Berkes, The Development of Secularism in Turkey; Ahmad, The Making of Modern Turkey; Karpat, The Politicization of Islam; Ergil, "Muhafazakâr Düşüncenin Temelleri."

27. Barış, "Muhafazakar Düşüncenin Temel Değerleri."

28. Niyazi Berkes' works, for instance, collate conservatism with a simplistic reactionary traditionalism, reducing the intellectual and political currents of Early Republican conservatism to reactionary cultural sensibilities coming from outside the political centre. Berkes, The Development of Secularism in Turkey, 51-62, 446-472, 500. Kemal Karpat has a relatively more complicated picture of conservatism as a sensibility that could be observed among Anatolian merchants, as well as emerging urban elites, and even the bureaucratic establishment. However, he also maintains a definition of conservatism as a centrifugal force, pushing the centre towards appeasing 'reactionary' sensibilities. Karpat, Social Change and Politics in Turkey, 315-20. Şerif Mardin's studies on Islamic movements underline the authoritarian and centralist nature of Turkish modernism and Kemalist ideology, which was countered by the centrifugal political rise of conservative and Islamic movements. Mardin, "Religion and Secularism in Turkey"; "Centre-Periphery Relations: A Key to Turkish Politics?"; "Religion and Politics in Modem Turkey"; Heper, "Centre and Periphery in the Ottoman Empire with Special Reference to the Nineteenth Century"; Parla, Türkiye'de Siyasal Kültürün Resmi Kaynakları 1-2-3; Arat, The Project of Modernity and Women; Toprak, Islam and Political Development. In the 1990s and 2000s, many critical academic studies on the hold of the Kemalist 'official history thesis' and 'official ideology' heavily relied on Mardin's centre-periphery argument, viewing Kemalist modernism as an authoritarian central force that exorcized and projected conservative ideology on 'people,' peripheral social actors.

29. Aktay, "İslamcilıktaki Muhafazakar Bakiye"; Akdoğan, Muhafazakar Demokrasi; Çaha, Dört Akım Dört Siyaset.

30. Çaha, Dört Akım Dört Siyaset, 126.

31. Birinci, Tarihin Hududunda. For a criticism of this approach to these writings as an 'alternative,' see Hanioğlu, "Kâzım Karabekiri Nasıl Tarihselleştirelim?" 
32. Akyol, Gayri Resmi Yakın Tarih.

33. Zürcher, Political Opposition; Turkey: A Modern History; Men of Order; Hanioğlu, Atatürk: An Intellectual Biography; The Young Turks in Opposition; Ahmad, "The Republican People's Party."

34. Zürcher, "Were the Progressives Conservative?"

35. İrem, "Kemalist Modernizm"; "Muhafazakar Modernlik"; “Turkish Conservative Modernism"; "Cumhuriyetçi Muhafazakarlık"; Aytürk, "Nationalism and Islam"; Aytürk and Mignon, "Paradoxes of a Cold War Sufi Woman."

36. İrem, "Turkish Conservative Modernism," 92.

37. Philliou, "When the Clock Strikes Twelve."

38. Balistreri, "Turkey's Forgotten Political Opposition."

39. Kirk, "Burke and the Principle of Order."

40. Ibid., 187-9.

41. Beyond moral corruption, the word 'fesat' also refers to illegitimate and disruptive political behaviour. Since nineteenth century, this word and its variations (like müfsid or fasid) are often invoked to describe opponents, insurgents and revolutionaries (from CUP to Hunchaks), especially during the Hamidian era. Furthermore, Orbay's own descriptions of 'etraf (as müfsids who had hidden motives and resorted to 'komitacılık') also reiterates these larger meanings of the term.

42. Kirk, The Conservative Mind, 8.

43. Kirk writes the following about Burke's criticisms of the revolutionary elite and quotes him directly ("Burke and the Principle of Order," 200-1):

Against an 'elite' recruited out of conformity to party fanaticism and enthusiastic adherence to a shallow and venomous intellectual credo, Burke wrote in the second letter of the Regicide Peace: 'To them, the will, the wish, the want, the liberty, the toil, the blood of individuals is nothing. Individuality is left out of their scheme of government. The state is all in all (...) The state has dominion and conquest for its sole objects; dominion over minds by proselytism, over bodies by arms.' These were, of course, the Jacobins; the description applies as well, or even better, to the Communist and the Nazi rule of an 'elite'.

44. Canefe, "Turkish Nationalism and Ethno-Symbolic Analysis," 134-8; Aytürk, "Nationalism and Islam"; Bora, "Nationalist discourses in Turkey."

45. Heper, "The State Tradition in Turkey," 50.

46. Cebesoy, Milli Mücadele Hatıraları, 562.

47. Zürcher, "Young Turk Memoirs as a Historical Source"; "Were the Progressives Conservative?"; Political Opposition in the Early Turkish Republic; Hanioğlu, The Young Turks in Opposition; Atatürk: An Intellectual Biography, "Garbcilar: Their Attitudes toward Religion."

48. Karabekir, Günlükler II, 1010.

49. Cebesoy, Siyasi Hattralar, 498.

50. Cebesoy, Siyasi Hatıralar, 511.

51. Cebesoy, Siyasi Hatıralar, 514.

52. Karabekir, Günlükler II, 976.

53. Zürcher, "Were the Progressives Conservative?" 244.

54. Ibid.

55. Mustafa Kemal's closest associate and successor as the president after his death. 
56. Zürcher, "Were the Progressives Conservative?" 245.

57. Orbay, Siyasi Hattralar, 322.

58. Cebesoy, Siyasi Hatıralar, 515.

59. The apparent contradiction that arises here is endemic to their conservatism: while Karabekir, Cebesoy and Orbay reiterate the repressive and elitist nature of etraf again and again, their emphasis is on the disconnect between the RPP and the will of the nation, since etraf and the RPP leaders lack the moral character to occupy the leadership positions they reserved for themselves. On the other hand, "those of strong personal convictions and moral character" are presented as a natural fit for leadership.

60. Zürcher, Turkey: A Modern History, 166-76; Ahmad, The Making of Modern Turkey, 52-71.

61. Komitacilik refers to the culture of rebel bands that developed in the Balkans during the nineteenth century, in particular. And as such it has been considered as part of the para-military political culture of the Committee for Union and Progress that relied on underground networks. Most Islamist political movements continued Orbay's perspective and occasionally argued that the Independence tribunals (Ístiklal Mahkemeleri) that tried individuals associated with Islamic insurgencies in Anatolia were actually controlled by komitacı networks, executing individuals at will.

62. Orbay, Siyasi Hatıralar, 350.

63. Orbay, Siyasi Hatıralar, 121-8; 167; 182-9; 226-30; 245-50.

64. Cebesoy, Siyasi Hatıralar, 646.

65. Karabekir, Günlükler II, 927.

66. Karabekir, Günlükler II, 964; 1010; 1077.

67. Karabekir, İstiklal Harbimiz, 1.

\section{Acknowledgements}

The author would like to thank the editor and anonymous reviewers for their insightful comments on the manuscript during the peer review process. The author would also like to thank Samil Can for carefully reading earlier versions of this article and providing useful feedback on Turkish political history and conservatism.

\section{Disclosure statement}

No potential conflict of interest was reported by the author.

\section{Funding}

This work was supported by the TÜBİTAK [grant number 1649B030700456].

\section{Note on contributor}

Yasemin Ipek is a Doctoral Candidate at the Department of Political Science and Public Administration, Bilkent University, Ankara. She holds Master of Arts and Bachelor of Arts degrees in Political Science and International Relations, and a Bachelor of Arts degree in Sociology, from Boğaziçi University, İstanbul. 


\section{Bibliography}

Adak, Hülya. "National Myths and Self-Na(rra)Tions: Mustafa Kemal's Nutukand Halide Edib's Memoirs and The Turkish Ordeal." South Atlantic Quarterly 102, no. 2-3 (2003): 509-527.

Ahmad, Feroz. “The Republican People's Party: 1924-1925.” In Political Parties and Democracy in Turkey, edited by Metin Heper, and Jacob Landau, 65-82. London: I. B. Tauris, 1990.

Ahmad, Feroz. The Making of Modern Turkey. New York: Routledge, 2002. Akdoğan, Yalçın. Muhafazakar Demokrasi. İstanbul: Alfa Yayınları, 2004.

Aktay, Yasin. "İslamcllıktaki Muhafazakâr Bakiye." In Modern Türkiye'de Siyasi Düşünce, Vol. 6: İslamcılık, edited by Ahmet Çiğdem, 346-360. İstanbul: İletişim yay., 2003.

Akyol, Mustafa. Gayri Resmi Yakın Tarih. İstanbul: Etkileşim Yayınları, 2011.

Alaranta, Toni. "Mustafa Kemal Atatürk's Six-Day Speech of 1927: Defining the Official Historical View of the Foundation of the Turkish Republic." Turkish Studies 9, no. 1 (2008): 115-129.

Anderson, Linda. Autobiography. New York: Routledge, 2001.

Arat, Yeşim. Rethinking Islam and Liberal Democracy: Islamist Women in Turkish Politics. Albany: SUNY Press, 2005.

Armağan, Mustafa. Efsaneler ve Gerçekler: Küller Altında Yakın Tarih. İstanbul: Timaş, 2007.

Armağan, Mustafa. Paşaların Hesaplaşması. İstanbul: Timaş, 2010.

Atatürk, Kemal. Nutuk, Volume 1. İstanbul: Milli Eğitim Basımevi, 1969.

Atatürk, Kemal. Nutuk. Volume 2. İstanbul: Milli Eğitim Basımevi, 1970.

Ateş, Nevin Yurdsever. Türkiye Cumhuriyetinin Kuruluşu ve Terakkiperver Cumhuriyet Fırkası. İstanbul: Sarmal Yayınevi, 1994.

Aytürk, İlker. "Nationalism and Islam in Cold War Turkey, 1944-69.” Middle Eastern Studies 50, no. 5 (2014): 693-719.

Aytürk, İlker, and Laurent Mignon. "Paradoxes of a Cold War Sufi Woman." New Perspectives on Turkey 49 (2013): 57-89.

Bahadıroğlu, Yavuz. Osmanlı Demokrasisinden Türkiye Cumhuriyetine. İstanbul: Nesil Yayınları, 2010.

Balistreri, Alexander E. “Turkey's Forgotten Political Opposition: The Demise of Kadirbeyoğlu Zeki Bey, 1919-1927.” Die Welt des Islams 55, no. 2 (2015): 141-185.

Barış, İsmail. "Muhafazakar Düşüncenin Temel Değerleri Çerçevesinde AK Parti." Muhafazakar Düşünce 11, no. 41-42 (2014): 237-255.

Berkes, Niyazi. The Development of Secularism in Turkey. Montreal: McGill University Press, 1964.

Birinci, Ali. Tarihin Hududunda Hatırat Kitapları, Matbuat Yasakları ve Arşiv Meseleleri. İstanbul: Dergah Yayınları, 2012.

Bora, Tanil. "Nationalist Discourses in Turkey." South Atlantic Quarterly 102, no. 2-3 (2003): 433-451.

Burke, Edmund. Reflections on the Revolution in France. Indianapolis: Bobbs-Merrill Educational Publishing, 1952.

Çaha, Ömer. "The Inevitable Coexistence of Civil Society and Liberalism.” Journal of Economic and Social Research 3, no. 2 (2001): 35-50.

Çaha, Ömer. Dört Akım Dört Siyaset. İstanbul: Orion Kitabevi, 2012.

Canefe, Nergis. "Turkish Nationalism and Ethno-symbolic Analysis: The Rules of Exception.” Nations and Nationalism 8, no. 2 (2002): 133-155.

Cebesoy, Ali Fuat. Milli Mücadele Hatıraları. İstanbul: Temel, 2000. 
Cebesoy, Ali Fuat. Siyasi Hattralar. İstanbul: Temel, 2007.

Çiğdem, Ahmet. Muhafazakarlı, Modern Türkiye'de Siyasi Düşünce. İstanbul: İletişim yay., 2009.

Ergil, Doğu. "Muhafazakar Düşüncenin Temelleri." Ankara Üniversitesi SBF Dergisi 41, no. 1 (1986): 269-292.

Erman, Azmi Nihat. İzmir Suikastı ve İstiklâl Mahkemeleri. İstanbul: Temel, 1971.

Ersanlı, Büşra. İktidar ve Tarih: Türkiye'de "Resmî Tarih" Tezinin Oluşumu (19291937). İstanbul: İletişim Yayınları, 2003.

Ertürk, Hüsamettin. İki Devrin Perde Arkası. Edited by Samih Nafiz Tansu. İstanbul: Hilmi Kitabevi, 1957.

Feulner, Edwin. "The Roots of Modern Conservative Thought from Burke to Kirk." First Principles Series Report 19. The Heritage Foundation, 2008.

Frey, Frederick. The Turkish Political Elite. Cambridge, MA: The M.I.T. Press, 1965.

Göçek, Fatma Müge. "Defining the Parameters of a Post-nationalist Turkish Historiography Through the Case of the Anatolian Armenians." In Turkey Beyond Nationalism: Towards Post-Nationalist Identities, edited by Hans-Lukas Kieser, 85. London: I. B. Tauris, 2006.

Gürler, Hamdi. Paşaların Gözüyle Milli Mücadele. İstanbul: Vadi Yayınları, 2007.

Gürpınar, Doğan. "The Politics of Memoirs and Memoir-Publishing in Twentieth Century Turkey." Turkish Studies 13, no. 3 (2012): 537-557.

Hanioğlu, M. Şükrü. The Young Turks in Opposition. New York: Oxford University Press, 1995.

Hanioğlu, M. Şükrü. Atatürk: An Intellectual Biography. Princeton, NJ: Princeton University Press, 2011.

Hanioğlu, M. Şükrü. “Kâzım Karabekir'i Nasıl Tarihselleştirelim?” Derin Tarih 1, Nisan (2012): 62.

Heper, Metin. "Center and Periphery in the Ottoman Empire with Special Reference to the Nineteenth Century." International Political Science Review 1 (1980): 81104.

Heper, Metin, and Jacob M. Landau. Political Parties and Democracy in Turkey. London: I. B. Tauris, 1990.

Heper, Metin, and Sabri Sayar,, Political Leaders and Democracy in Turkey. Lanham, MD: Lexington Books, 2002.

Hunsacker, S. V. Autobiography and National Identity in the Americas. Charlottesville: University Press of Virginia, 1999.

İnam, Erberk. Rauf Bey. İstanbul: Deniz Basımevi, 1965.

İnönü, İsmet. Hatıralar. İstanbul: Bilgi Yayınevi, 1997.

İrem, Nazım. "Kemalist Modernizm ve Türk Gelenekçi Muhafazakarlığının Kökenleri.” Toplum ve Bilim 74, Fall (1997): 52-99.

İrem, Nazım. "Muhafazakar Modernlik, 'Diğer Batı' ve Türkiye'de Bergsonculuk." Toplum ve Bilim 82 (1999): 141-179.

İrem, Nazım. "Turkish Conservative Modernism: Birth of a Nationalist Quest for Cultural Renewal.” IJMES 34, no. 1 (2002): 99-100.

Kandemir, Feridun. İzmir Suikastının İçyüzü. İstanbul: Ekicigil, 1955.

Kandemir, Feridun. Hâtıraları ve Söyleyemedikleri ile Rauf Orbay. İstanbul: Yakın Tarihimiz Yayınları, 1965.

Kaplan, İsmail. Türkiye’de Milli Eğitim İdeolojisi. İstanbul: İletişim Yayınları, 2002.

Karabekir, Kazım. İstiklal Harbimizin Esasları. İstanbul: Sinan Matbaası Neşriyat Evi, 1951.

Karabekir, Kazım. İstiklal Harbimiz. İstanbul: Türkiye Yayınevi, 1960. 
Karabekir, Kazım. Günlükler, Cilt 1-2. İstanbul: Yapı Kredi Yayınları, 2009.

Karpat, Kemal H. Social Change and Politics in Turkey. A Structural-Historical Analysis. Leiden: E. J. Brill, 1973.

Karpat, Kemal H. The Politicization of Islam: Reconstructing Identity, State, Faith, and Community in the Late Ottoman State. Oxford: Oxford University Press, 2002.

Kirk, Russell. "Burke and the Principle of Order." The Sewanee Review 60 (April-June 1952): 187-201.

Kutay, Cemal. Üç Devirde Bir Adam. İstanbul: Tercüman, 1980.

Kutay, Cemal. Osmanlidan Cumhuriyet'e: Yüzyılımızda bir İnsanımız, Hüseyin Rauf Orbay, 1881-1964. İstanbul: Kazanç Kitap Ticaret, 1995.

Lewis, Bernard. The Emergence of Modern Turkey. Oxford: Oxford University Press, 2001.

Mardin, Şerif. “Centre-Periphery Relations: A Key to Turkish Politics?” Daedadus 102, no. 1 (1973): 169-190.

Mardin, Şerif. "Religion and Politics in Modern Turkey." In Islam in the Political Process, edited by James Piscatori, 144-151. Cambridge: Cambridge University Press, 1984.

Mardin, Şerif. "Religion and Secularism in Turkey." In The Modern Middle East: A Reader, edited by Albert Hourani, Philip Shukry Khoury, and Mary Christina Wilson, 347-374. Los Angeles: UC California Press, 1993.

Moore-Gilbert, Bart. Postcolonial Life-Writing: Culture, Politics, and SelfRepresentation. New York: Taylor \& Francis, 2009.

Mumcu, Uğur. Kazım Karabekir Anlatıyor. İstanbul: Uğur Mumcu Vakfı Yayınları, 2009.

Öğün, Süleyman Seyfi. “Türk Muhafazakârlığının Kültürel ve Politik Kökleri ve Peyami Safa'nın Muhafazakar Yanılgısı.” Toplum ve Bilim: Türk Muhafazakarlı̆̆ 74 (1997): 102-152.

Orbay, Rauf. Cehennem Değirmeni: Siyasi Hatıralarım 2. İstanbul: Emre Yayınları, 2000.

Orbay, Rauf. Siyasi Hatıralar. İstanbul: Örgün Yayınevi, 2003.

Özcan, Ahmet. Türkiye'de Popular Tarihçilik: 1908-1960. Ankara: Türk Tarih Kurumu, 2011.

Parla, Taha. Türkiye'de Siyasal Kültürün Resmî Kaynakları, Cilt 1-2-3. İstanbul: İletişim Yayınları, 1991.

Philliou, Christine. "When the Clock Strikes Twelve: The Inception of an Ottoman Past in Early Republican Turkey." Comparative Studies of South Asia, Africa and the Middle East 31, no. 1 (2011): 172-182.

Poulton, Hugh. Top Hat, Grey Wolf and Crescent. New York: New York University Press, 1997.

Rustow, Dunkwart. "Political Parties in Turkey: An Overview." In Political Parties and Democracy in Turkey, edited by Metin Heper, and Jacob Landau, 10-24. London: I. B. Tauris, 1990.

Smith, S., and J. Watson. De-Colonizing the Subject: The Politics of Gender in Women's Autobiography. Minneapolis: University of Minnesota Press, 1992.

Toprak, Binnaz. Islam and Political Development in Turkey. Leiden: E. J. Brill, 1981.

Whitlock, G. Postcolonial Life Narratives: Testimonial Transactions. Oxford: Oxford University Press, 2015.

Yavuz, Hakan. Modernleşen Müslümanlar/Nurcular, Nakşiler, Milli Görüş ve AK Parti. İstanbul: Kitap Yayınları, 2008. 
Yeşil, Ahmet. Türkiye Cumhuriyeti'nde İlk Teşkilatlı Muhalefet Hareketi. İstanbul: Cedit Neşriyat, 2002.

Yıldız, Zekeriya. Küskün Paşalar. İstanbul: Nesil Yayınları, 2009.

Zürcher, Erik J. Political Opposition in the Early Turkish Republic: The Progressive Republican Party, 1924-1925. Leiden: E. J. Brill, 1991.

Zürcher, Erik J. Turkey: A Modern History, Revised Edition. London: I. B. Tauris, 2004.

Zürcher, Erik J. “Were the Progressives Conservative?” In The Young Turk Legacy and Nation Building: From the Ottoman Empire to Ataturk's Turkey. London: I. B. Tauris, 2010.

Zürcher, Erik J. "Young Turk Memoirs as a Historical Source: Kâzım Karabekir's İstiklâl Harbimiz." In The Young Turk Legacy and Nation Building: From the Ottoman Empire to Ataturk's Turkey, 17-25. London: I. B. Tauris, 2010.

Zürcher, Erik J. The Young Turk Legacy and Nation Building: From the Ottoman Empire to Ataturk's Turkey. London: I. B. Tauris, 2010.

Zürcher, Erik J., and Touraj Atabaki, eds. Men of Order: Authoritarian Modernization Under Atatürk and Reza Shah. London: I. B. Tauris, 2003. 